\section{Appreciation: Dr. H. M. S. S. D. Herath}

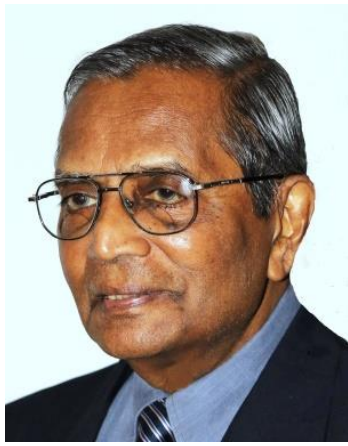

Dr. H. M. S. S. D. (Ananda) Herath was an upright medical professional who was dedicated to community medicine.

He worked as a Medical Officer of Health $(\mathrm{MOH})$ from 1966 to 1968. As $\mathrm{MOH}$ Eheliyagoda he took part in the mass campaign to control polio with the newly introduced oral polio vaccine. As $\mathrm{MOH}$ Padukka he introduced direct pit water-seal latrines.

I came to know him when we flew together to London in 1972, to follow the course for the Diploma in Tropical Public Health at the London School of Hygiene and Tropical Medicine of the University of London. As Ananda was on a fellowship to study occupational health he stayed back and followed the course for the Diploma in Occupational Health at the same institution.

On his return to Sri Lanka he worked as Senior Medical Officer Environmental and Occupational Health (SMO E\&OH) in the Ministry of Health.

The diploma we had was recognized by the Ministry of Heath as a part specialist qualification. The full specialist qualification was a diploma and the MD or MRCP. The Ministry allowed no pay leave abroad to get the MRCP. Ananda did the rare thing of proceeding to England again and obtaining the MRCP. However, as a person who had opted for public health he remained in public health.

He was Director (E \& OH) from 1987-1991. During this period he edited the Manual of the Sri Lanka Public Health Inspector and the book Occupational Health: an introductory course for health workers, both for the Ministry of Health. He was a member of the WHO Expert Panel on Occupational Health.

He ended his career in the Ministry of Health as Deputy Director General Public Health Services (1991-97). During this period the National Sexually Transmitted Diseases and AIDS Control Programme (NSACP) came under his purview. He was a member of the National AIDS Committee during this period.

He was President of the College of Community Physicians of Sri Lanka. He was an active member of the Board of Study in Community Medicine of the Post graduate Institute of Medicine (PGIM), University of Colombo. He was Course Unit Advisor in Environmental and Occupational Health for the MSc course in Community Medicine and teacher and examiner at the MSc and MD in Community Medicine.

He was a joint editor of the publication 'Public Health Development in Sri Lanka', the Millennium Supplement of The Journal of the College of Community Physicians of Sri Lanka. He was also the President of College of Medical Administrators of Sri Lanka.

He was a member of the Board of Study in Medical Administration of the PGIM and was the Course Director in Public Health Administration for the MSc in Medical Administration.

He was a Fellow of the College of Community Physicians of Sri Lanka, the College of Medical Administrators of Sri Lanka and the Ceylon College of Physicians.

After retirement he made a contribution to HIVAIDS control in Sri Lanka by working as Training Coordinator to the NSACP, IDA/World Bank Health Services Project $(1999$ - 2001) and as Consultant and Management Specialist for the IDA/World Bank assisted National HIV/AIDS Prevention Project (2002-2006). 
He also actively collaborated with the newly formed Sri Lanka College of Venereologists. The College which is now called the College of Sexual Health and HIV Medicine is grateful for his contribution to the development of venereology in Sri Lanka.

He served the Sri Lanka Medical Council (SLMC) for 11 years, as Assistant Registrar and later as Acting Registrar for over two years. He retired from the SLMC about an year ago.

We met each other monthly at the council meetings of the Independent Medical Practitioners Association.

He leaves behind Antoinette, retired Senior Consultant Rheumatologist of the National Hospital of Sri Lanka and three children. His daughter Deepika is following his father's footsteps and specializing in community medicine.

Ananda was a good friend, and a straight speaking honest medical professional of whom his family could be proud.

May He Rest in Peace.

\section{Dr Lucian Jayasuriya}

Founder President of the Sri Lanka College of Venereologists

Formerly Additional Secretary, Ministry of Health, Sri Lanka 